\title{
Oil Exploration and Security Challenges in the Niger-Delta Region: A Case of Akwa Ibom State, Nigeria
}

\author{
Phenson Ufot Akpan \\ Ph.D. student of the Department of Political Science \& Public Administration, Faculty of Social Science of the \\ University of Uyo, Uyo, Akwa Ibom State, Nigeria
}

\begin{abstract}
It is true that the discovery of oil and gas deposits in regions and countries of the world is often a blessing. However, the accompanying security and environmental challenges that heralded the exploration and production of oil and gas in any region of the world, can best be described as dangerous and a curse in some countries. This is due to the pollutions arising from gas flaring and oil spillages which often lead to serious health hazards, damages to the environment, social, cultural and occupational displacements, destruction of means of livelihoods and violations of human rights which adversely affect peace and security. The long neglect of host oil-bearing communities which manifest in the non-provision of basic development infrastructures such as lack of good sources of drinking water, electricity supply, good roads, health and educational facilities, lack of employment opportunities, and deliberate delays by oil producing companies to compensate for oil spills and gas flaring effects and at times, outright refusals to remediate such polluted sites often generate confrontations between oil companies and their host communities. The re-occurring environmental degradations and pollutions arising from gas flaring and oil spillages culminate in rising frustrations and consequent rebellions by youths of oil-rich, but unfortunately neglected Niger-Delta in particular and Akwa Ibom State in general. The futile attempts by the Nigerian central government to use military forces to suppress genuine demands from these regions, have always failed and often lead to stiff resistance and resort to arms-struggles and militant reprisals with consequences on peace, security and loss of lives on both warning parties. It is this abysmal relationship between the oil companies and the oil host communities that breeds regular conflict and security threats that this paper is predicted upon. This study vividly examines the impact of oil exploration on the internal security of the Niger-Delta with a particular attention on Akwa Ibom State of Nigeria.
\end{abstract}

Key Words: Oil exploration, Security challenges, Niger-Delta, Environmental problems, and Oil spillages.

\section{Introduction}

Akwa Ibom State is one of the thirty-six states that make-up Nigeria and one of the nine oil and gas producing states of the Niger-Delta region in Nigeria. Nine out of thirty-six states in Nigeria, including Abuja the Federal Capital are oil producing and the states are strategically and gloriously located in the Niger-Delta region. These are; Abia, Bayelsa, Cross River, Edo, Imo, Ondo, Rivers and Delta States (Ekpo, 2004). Akwa Ibom State is geographically located in the South-South Geo-Political zone of Nigeria with an estimated population of 3,902,051 million people (NPC, 2006, B. 23). The people speak three major languages of Ibibio, Annang, Oron and others like Obolos and Ibeno speak Andoni.

Cartographically, the state is located in the South-South geo-political zone of Nigeria between latitude $4^{\circ} 3^{\circ}$ and $5^{\circ} 32^{\circ}$ North of the equator and longitude $7^{\circ} 25^{\circ}$ and $8^{\circ} 3^{\circ}$ East of the Greenwich meridian (Esin 2012:8). Politically, the state has three senatorial districts and ten federal constituencies with thirty-one Local Government Areas.

The traditional occupation of the people of the state are mainly farming, fishing, raffia and hand crafts, commerce and petty trading, timber logging and palm oil production until in modern times, oil and gas production which has been generating spates of security-related challenges which this paper is set to examine.

Oil spillages and gas flaring are common occurrences in Nigeria's oil industry. Available data shows that since 1989, Shell Petroleum Development Company (SPDC), one of the giant oil companies in the Niger-Delta region has recorded an average of 221 oil spills per-year involving a total of 7,350 barrels spills annually (SPDC, 2000). Also, 40,000 barrels of light crude oil were spilled in 1998 by Exxon-Mobil in Eket (Da Costa, 1999).

Similarly, statistics also reveal that a total of 2,796 oil spills were recorded in Nigeria between 1976 and 1990, resulting in the spilling of 2,105,393 barrels of oil. Again, three million barrels of oil were lost due to 6,817 oil spill incidents between 1976 and 2001 and over $70 \%$ of the spilled oil was not recovered (UNDP, 2006) in (Ekpenyong 2010). The re-occurring and indiscriminate manner with which oil and gas companies damage the environment through incessant oil spills that result from out-dated and ill-maintained oil pipeline grids are alarming and are some of the reasons for continued security challenges common to oil bearing communities in Akwa Ibom State. 
However, the non-remediation of polluted sites by oil companies and non-payment of compensation to the impoverished and poorly developed oil communities in Akwa Ibom State tend to generate open confrontations and security challenges in the oil producing areas of the state. These have acted as in-road to full blown conflicts in the region.

Consequently, the nine states of the region are witnessing plethora of rebellious groups calling for selfdetermination. Some indigenes of the region are using these reactionary forces to unleash terror on the Nigerian state and officials of foreign oil companies operating in Nigeria (Phenson, 2008). Violence, in the Niger-Delta communities and indeed Akwa Ibom State is actually both a response to the violence of the state, an attempt at attracting attentions to their plights. It is this negative relationship between oil exploration, peace and the internal security of Akwa Ibom State that this paper is predicated upon.

\section{Statement Of The Research Problem:}

The denial of the people of the oil producing communities of Akwa Ibom State and the Niger-Delta in general of their rights and privileges by the oil and gas Trans-national Corporations operating in the region has generated serious conflicts. These conflicts in the state are based on the following classifications;

- $\quad$ Conflicts within the oil bearing communities arising from divide and rule policy of the oil companies.

- $\quad$ Conflicts between the host oil communities and the government.

- Conflicts between the host oil communities and the oil companies.

- $\quad$ Conflicts between two different communities or states. For instance, the case between Cross River State and Akwa Ibom State, Rivers State and Akwa Ibom State, Rivers State and Bayelsa State, etc

It is unfortunate that from 1958 when crude oil was discovered in some parts of the region till date, development is still illusive in the Niger-Delta region. This has brought about violence and conflicts of serious dimension on daily basis. Following this widespread violence and insecurity, the Nigerian state have been directly using the armed forces and police who engaged in extra-judicial killings, and other means to check-mate the host communities from making their demands, thus trampling on their fundamental human right. There have been a long and bitter conflicts of interest, struggles, disagreement, controversies, fighting and clashes between oil producing areas and oil and gas Trans-national Corporations.

The Niger-Delta has suffered the degradation effects of oil exploration and exploitation. Land, streams and creeks are totally and continually polluted, the atmosphere is forever charged with hydro-carbon monoxide and carbon dioxide. Many villages experienced the internal quaking of the wrath of gas flames. The substances generated into the air in form of vapour, carbon monoxide and dioxide are innumerable. It is only oil producing areas in Nigeria that had acknowledged the environmental degradation of oil activities and the effects on man and his economic survival (Leton, 1990).

These have made bands of armed protesting civilians to take over flow stations, forcing oil companies to shut down their occupied production platforms in some parts of the region. Many criminally-minded persons in the region have hidden themselves under this prolonged crisis situation to perpetuate various kinds of criminal activities including; kidnappings, illegal bunkering, vandalization of oil and gas pipelines, high-profile robberies, hostage-takings and actual terror act directed against governments and oil companies which the people always hold responsible for their mis-fortunes.

The Niger-Deltans are aggrieved that government had no well taught plans of sustainable development. It has no favourable policy on security of the degraded environment, lives and property of the people and no oil spill compensation policy. Instead of government making good policies to address oil-related problems as it affect the people on daily basis in the Niger-Delta region, it goes ahead to formulate exploitative laws / policies and actions which are intended to protect the interest of oil companies to the detriment of the host oil communities. These include; the land use decree of 1978, petroleum decree No. 51 of 1969, petroleum production and distribution (anti-sabotage) degree 1975, oil terminal dues act 1965 and oil royalties, rent and revenue allocation among others without effort to amend any of the acts in line with global practices. An attempt on the petroleum act currently before the National Assembly has not been pass to law. This situation has become a big threat to the Nigerian nation and has been the major sources of insecurity in Akwa Ibom State in particular and the Niger-Delta in general.

This therefore shows an apparent relationship between insecurity and operations of oil and gas producing companies in Nigeria. Security challenges in the region are build-up of failure of the Nigerian governments (federal, states and local government councils) to timely address the demands of host oil communities, who are made to suffer environmental devastation, loss of means of economic livelihoods, etc because of the exploitative activities of oil companies. This makes oil exploitation and insecurity mutually reinforcing.

The continued oil spills, the non-compensation and delayed remediation among other reasons often pitch the oil communities against operating oil companies in the host region. This is coupled with the lopsided employment quota system being operated in Nigerian oil industry, whereby more lucrative job positions are 
assigned to only foreign oil workers while the few indigenous oil workers are employed as contract staff to do menial jobs that attract meager pays. There are lacks of infrastructural developments in the oil producing areas, lack of health and educational facilities, lack of good roads networks, lack of good water supplies since all sources of good drinking water have been long contaminated by the operations of the rampaging oil prospecting companies in these regions, which now generate insecurity.

The re-occurring oil spills and the protracted environmental pollutions that have continued to devastate the environments, the aquatic means of livelihood and the destruction of wildlife, forest reserves, sources of water supplies, contamination of rivers and farmlands and the degradation that arise from both gas flaring and continued oil spills are common problems that generate insecurity in Akwa Ibom State and other oil producing areas of the Niger-Delta region of Nigeria.

In Akwa Ibom State of Nigeria, communities like Ikot-Ada Udo in Ikot Abasi Local Government Area, Ikot Ebidang in Onna Local Government Area, Ibeno in Ibeno Local Government Area, EsitEket Local Government Area, Eket in Eket Local Government Area and communities along the coastal oil belts of EasteernObolo Local Government Area and the Bonga off shore oil wells of Mbo Local Government Area, are experiencing similar protracted security challenges arising from oil-related security and environmental problems.

Ironically, despite the huge oil revenues and wealth generated in these oil producing states of Nigeria, the indigenous host communities had continued to suffer from protracted deprivation, pervasive poverty in the midst of oil wealth, lack of full time job opportunities in these foreign oil companies operating in their domains. The above lopsided employment quota and the lack of general development in these host oil communities of the state, coupled with the ever-increasing environmental pollutions which are often neglected and not remediated nor compensated for, that constantly trigger-off conflicts, youths restiveness and violent agitations for redress of the above anomalies by the Nigerian state and oil conglomerates.

\section{Theoretical Framework:}

A Theory is a set of facts, propositions, principles, ideas or beliefs arrived at through assumptions employed to analyze relationship between variables that help in explaining phenomenon and solve a given problem (Cohen 1968:2). The use of theories in this work is important because these will explain the correlation between oil/gas exploration and insecurity in Akwa Ibom State.

In relation to the above explanation, this work adopts Frustration-Aggression Theory in explaining the security-related problems that arise from oil and gas producing company's operations in Akwa Ibom State in particular and the Niger-Delta in general.

The issue of the estranged economic and working relationship between oil companies and their host communities can be better explained using the Frustration - Aggression Theory propounded by John Dollard (1939).

The theory tends to explain violent behaviors that result from inability to fulfill needs. For instance, where expectation does not meet attainment, the tendency is for the people to confront those they hold responsible for frustrating their ambitions. The greater the difference between what is sought for and what is attainable, the greater the chances that anger and violence will result. (Gurr 1970:24).

It is on the premise of above theory that one can explain the untoward and violent reactions by long-neglected host indigenous oil communities whose frustrations over non-compensations for the numerous environmental damages and pollutions of their lands have led to continued aggressive attitudes of such host communities towards oil companies operating and devastating their oil bearing communities.

\section{Methodology:}

This work adopts a method that is purely descriptive. Thus, secondary sources formed the core of data gathering machinery or processes on which the analysis adopted in this study were anchored.

Secondary sources such as relevant textbooks, Journals, Newspapers, Internet and Government Gazettes, published and unpublished documents, formed major secondary sources of research data analyzed. Similarly, personal oral interviews and observations were utilized for analytical insights into security challenges arising from the relationships between oil producing companies, the Nigerian state and the Akwa Ibom State host oil communities.

\section{Literature Review:}

The issue of security and its conceptualization has remained varied and viewed by many from different perspectives in history. However, a common agreement between these various views is that security is a condition of feeling safe from harm or danger and the protection of core values of an individual or a given society. According to Magstadt (2006), the goal of any state (government) is to provide a reasonable amount of security for its citizens. The 1999 constitution of the Federal Republic of Nigeria for instance, outlined one of 
the roles of the Nigerian State (government) as maintenance of security and well-being of citizens and securing public safety and order. Gana and Omelle (2006) stated one of the constitutional obligations of governments all over the world as accountability for the security of their countries and people from both domestic and international perspectives.

However, modern theorists such as Collins (2007), Yergin (1991) and Buzan (1983) see security as multi-disciplinary and from a multi-dimensional approach as an all-hazards and holistic approach that involves several departments working simultaneously to attain security goals and objectives collectively. This brings about the concept of collective security which involves citizens, private sector and government partnering together in ensuring the protection of lives and property of the citizens. It is from the above conceptualization of security as a government constitutional mandate that this paper will examine the oil-related security challenges that have characterized the ugly relationships existing between oil producing companies and their host communities in Akwa Ibom State.

The oil industry is the main-stay of the Nigerian economy as it attracts over $75 \%$ of its national revenues. Thus, oil sector in a state like Akwa Ibom State in Nigeria that generate such huge national revenues often attract federal government attention and protection of oil companies operating in such a state (Okowa, 2007). Abali, (1996) observed that crude oil contributes to public revenue in Nigeria through the following sources; rents, royalties, direct sales of government equity oil, NNPC earnings, petrol subsidy and level of production and on-going oil prices.

However, according to Osuoka, (2003), all stages of oil production from exploration, drilling to transportation, results in destruction of natural environment and the livelihoods of the local host communities who depend on the land, fishing and the often polluted rivers and creeks for their survival. Today, the people of the Niger-Delta region and indeed Akwa Ibom State remain emasculated and their God's given resources expropriated. The discovery of crude oil in the state and indeed Niger-Delta has become a curse to the people as the events in the country continue to show. The criminal exploitation of the Niger-Delta region has turned the region into a hot bed of crisis with the emergence of militant social movements such as the Movement for the Survival of Ogoni People (MOSOP), the Niger-Delta Volunteer Force (NDVF) and the Movement for the Emancipation of the Niger-Delta (MEND), among others (Ekpenyong, 2010).

Agbu, (2005) on his own, sees the combined incessant oil spills and accidental blow outs resulting from ill-maintained and over-aged oil pipelines and oil well heads, that makes Akwa Ibom State and other parts of the region to record highest incidence of oil spillages and environmental pollutions.

The UNDP report (2006) indicates that oil spillages and gas flaring are common occurrences in the Nigerian oil industry and that there were 6,817 oil spill incidents in Nigeria between 1976 and 2001 and over $70 \%$ of the spilled oil were not recovered and very few of these spill sites were not remediated till date.

It is such unwholesome scenarios indicated above that often pitch the host communities of these oil producing companies which lead to re-occurring spates of youths restiveness and violent reactions in demand for redress of environmental damage occasioned by operations of these oil companies which tend to exacerbate security challenges in oil producing communities. Amnesty International Reports of (2005) indicates that, though oil pollutions and spillages are enormous in Nigeria, these incidents have remained controversial because oil companies are reluctant to accept responsibilities and the attendant financial compensation. Some of the oil companies particularly, the Shell Producing Development Company (SPDC) and Exxon Mobil (Nig.) Unlimited have repeatedly denied responsibility to most oil spills, claiming that these were as a result of deliberate sabotage and pipeline vandalism by indigenous hoodlums and oil bunkerers.

The host oil communities, who bear the brunt of these re-occurring spills and their consequences on their lands and aquatic livelihoods, argue for redress and financial compensation pointing to industrial spills, drilling blow-outs and protracted legal battles meant to delay or deny payment of financial compensation to these unfortunate oil communities in several of such spills.

Karl (1991), agrees that accountability is the acknowledgement and assumption of responsibility for actions, decisions and policies, including administration, and implementation, the obligation to report, explain and be answerable for resulting consequences. Accountability in the Nigerian oil industry is lacking. Actually, lack of transparency in oil operations and sales in the Nigerian oil industry paints dark perfumes in the minds of an average Nigerian citizen. This is why Pezerworski (1988) states that the cardinal points of true democracy is the ability to institutionalize the principles of transparency and accountability on leaders, whereby they can be held accountable for their actions in the public domain by citizens indirectly through the competition and cooperation of their elected representatives. Apart from government, in Nigerian oil companies are not also accountable to their host oil communities due to tacit government protection and connivance of corrupt government officials in oil industry business.

SPDC Annual Report (2009) indicates that Shell made a total profit of \$31 billion during the year and currently gets $10 \%$ of its global output from Nigeria's oil blocks. This would have translated to huge revenue 
benefits to Nigeria through Joint-Venture share ratio with Nigeria. However, the evident corruption and lack of transparency in the Nigerian oil sector has not translated these huge oil revenues to the citizenry.

The World Bank Report (2000) indicates an alarming rate of un-employment amongst graduates in the oil rich Niger-Delta region in Nigeria which puts the unemployment in the region as high as $25 \%$ in the Nigerian labour market indices. Karl (2007) states that countries like Nigeria, Venezuela and Angola who depend on oil as their major resource for development are characterized by corruption and unemployment.

Ikporukpo (1983), Ikein (1991) and World Bank Reports (1995) all indicate that oil exploration and production have induced environmental degradations that have had consequences on oil losses, exacerbated poverty, caused occupational dis-orientation, social conflicts, population displacement and violations of human rights amongst indigenes of oil producing communities in the Niger-Delta region and elsewhere in the world. Oil producing companies operating in the Niger-Delta Regions of Nigeria have enjoyed federal government protection above all other government regulating agencies and thus, tends to operate with impunity and flout environmental protection laws at the detriment of their host oil communities whose polluted environments are left un-compensated for nor remediated (Okaba, 2005). Socio-economic deprivation, human rights and crisis prevalent in the Niger-Delta Region are within the ambit of the federal government of Nigeria. The state law's for instance, which had resulted in the spate of violence protests (insecurity) in Akwa Ibom State in particular and the Niger-Delta in general and has empowered the federal government of Nigeria to dispossess and disempowered the oil producing communities (Awosika, 2008).

It is the system of laws that barefaced exploitation of the oil producing communities by the Nigerian state and oil companies that is operating in the region. This point was collaborated by Ken Sarowiwa, the late hero of Ogoni struggle. He argues that the basic point about the development of oil producing area is a political one. According to Okabu (2005), revenue allocation lies very much at the heart of a federal system of government, oil is at the centre of the Nigerian Federation of this time. Consequently, most of the laws which govern the exploration of oil in Nigeria offend public morality and are oppressive in the extreme. These laws are decidedly opposed to those who own the oil bearing land (oil and gas host communities). It is the poor attitude of federal government towards amicably resolving oil-related security challenges occasioned by oil firms operations that tend to worsen insecurity in the state.

The sorry situation is that the oil and gas companies in the state (SPDC, Exxon Mobil Unlimited and Septa Energy (Nig) Ltd) among many others do not readily compensate the victims of their polluting sites nor remediate their damaged environments. Instead, the companies opt to engage in long-drawn or protracted legal battles resulting in the frustration, inevitable protests by the indigenes or actual death of the victims (Phenson, 2014).

In the Niger-Delta which Akwa Ibom State is part and parcel, eleven (11) oil companies are operating with 159 oil fields and 1,481 wells. In a report titled, "Ways of Using Oil Boom for Sustainable Development", published by the African Development Bank (ADB) (1997) Nigeria's total earnings from crude oil was put at \$ 600 billion (or about 84 trillion) in the past years. This according to Idehen (2008) should translate to over $\$ 1.8$ trillion per annum for 45 years.

\section{Discussion:}

The total neglect and marginalization of these minorities from the political and socio-economic life of the nation despite the bulk of oil tapped on daily basis from their communities, abject poverty and underdeveloped have made the minorities increasingly questioned the capacity of the Nigerian state to protect their welfare and meet their needs in the face of shrinking oil revenue and a locative system that is stacked against them. Today, poverty walks very tall on every street of Akwa Ibom State and indeed the Niger-Delta Region because of the mismanagement of the huge earnings from oil by the Nigerian government.

The most devastating effect of oil exploration in the region that have caused serious worries to the people is the increasing threats to the environment which manifests in various forms such as oil spillage which has deprived the people of their main sources of livelihoods(fishing and farming). This is because oil spills have inflicted unimaginable level of damage on farmlands and rivers such that the people can no longer sustain soil nutrients and aquatic resources. It was this dangerous situation that the Niger-Delta and indeed Akwa Ibom State isfacing that Idehen (2008) observes in his work "Militancy in The Niger-Delta" Implications for Nigeria's National and Sub-Regional Security that between 1997 and 1999, about 3000 oil spills were reported by the oil companies operating in Nigeria, translating into over 2 million barrels of oil spilled into the country's terrestrial, coastal and offshore marine environment. Apart from oil, gas flaring has also been a reoccurring issue in the Niger-Delta, with devastating effects on the environment, especially the degradation of the air. In 1991, about 30-35 million tons of carbon dioxide and an estimated 12 million tons a year of methane, which is very dangerous to the environment, were emitted into the atmosphere thus, increasing "Ambient Air Degradation" in the oil producing areas. 
Oil spillages and gas flaring are common to oil producing regions worldwide and Akwa Ibom State in particular. This is supported by the Shell Petroleum Development Company (SPDC) 2000 Report which says that, a total of three million barrels of crude oil were lost between 1976 and 2001 through 6,817 oil spill incidents by Shell operations in the Niger-Delta region in Nigeria. Agbu (2005) states that due to incessant oil spills and blow-outs resulting from over - aged and ill-maintained oil well heads and rusty oil pipelines, Nigeria oil field to record the highest number of oil spills in the whole world.

According to Osuoka (2003), all stages of oil activity from exploration, drilling and transportation result in the destruction of natural environment and consequently, the livelihoods of the local inhabitants who depend on the land and creeks of the Niger-Delta region for their survival are greatly affected. It is this unwholesome happenings, coupled with evident neglect in terms of lack of infrastructures, high rate of unemployment and ironic paradox of poverty amidst oil wealth that tend to frustrate local indigenes of the core oil bearing communities and force them to react to these unacceptable injustices and environmental devastations in their communities.

The impunity with which oil companies operate without regards to the World Acceptable Environmental Standards (WAES) and the tacit support and protection given by the Nigerian governments tend to spur these aggrieved local educated, but unemployed youths of oil producing communities to resort to militant and violence resistance in seeking redress of these abnormalities. The wrong policy of government in sending military forces to suppress genuine demands from these long-neglected oil communities also tend to make the local oil communities youth to embark to arm-struggle and militancy in self-defense against the vindictive and unwarranted killings occasioned by militarization policy of government aimed at quelling genuine demands from these oil communities. The lopsided unemployment job quota system which tends to allocate lucrative oil positions only to privilege foreign oil workers, and reducing indigenous oil workers to menial oil jobs where they work on contracts tend to frustrate and trigger these local youths to violence which worsen insecurity in oil sectors in the oil producing region.

\section{Conclusion:}

The non-challant attitude of government towards protecting host oil producing communities against environmental degradations consequent upon activities of oil companies in the oil producing areas of the region forms breeding ground for violent reactions and agitations from local oil communities for redress of such environmental injustices and neglect. This lack of strong government over-sight and regulatory enforcement is an injustice to the oil producing communities who bear the brunt of these environmental neglect and deprivations foisted on such communities due to operations of oil companies in their communities. Another source of crisis of militant dimension is lack of deliberate government policy to create job opportunities for restive, educated but, unemployed youths of the oil producing areas. The delays in responding to genuine demands to remedy above problems in such oil communities often result to confrontations and attempt by government with the tacit support of oil companies to suppress these agitations by indigenous oil communities. These have remained the bane of insecurity in the Niger-Delta and Akwa Ibom State.

The re-occurring oil spills and gas flares that be-devil oil producing region and Akwa Ibom State in particular can also be traced to human, security and environmental challenges being experienced in the region. Such security challenges are caused by incessant oil spills and gas flaring that accompanies oil explorations, leading to environmental degradation, the paradox of poverty in the midst of oil wealth, increasing unemployment existing amongst core-oil producing communities, lack of developmental infrastructures in these communities are ample grounds for confrontations.

Sometimes, outright refusal by oil companies to remediate polluted oil sites in these oil bearing communities often trigger-off agitations and confrontation that result in untoward and adverse security challenges in such oil and gas producing areas in Akwa Ibom State which this paper examines.

\section{The Way Forward:}

In order to address holistically the re-occurring oil related security problems occasioned by oil company's activities in oil bearing communities, the following measures are recommended as the way forward:

- The Nigerian federal government should as a matter of justice and economic necessity build oil/gas refineries in the Niger-Delta region where oil/gas rightly belong, rather than tap oil/gas through long pipelines across several millions of kilometers to develop the non-oil/gas communities of Nigeria. This long route transfer of oil encourages vandalization of oil/gas pipelines which has become so pronounced in the recent time.

- The Nigerian governments at all levels, should prevail upon oil/gas companies in the region to as a matter of urgency sign Memorandum of Understanding (MOU) with their host communities to meet-up with the developmental and job employment opportunity needs of the people. 
- Establishment of home-grown development master plan to address the issue of long neglect of oil producing communities.

- The government and other environment over-sight regulating agencies should as a matter of official expedienciency enforce compliance of oil companies to environmental world acceptable standards in the Niger-Delta

- There should be a deliberate plan by government to employ youths and ensure an appropriate employment quota system between foreign oil workers and their qualified indigenous counterparts in line with equity and justice.

- The government should ensure prompt remediation of all oil spill sites and enforce payment of compensation to affected oil and gas communities in event of oil spills and gas flares in such communities.

- The government should avoid the use of military forces in attempt to suppress genuine local demands for development and respect to environment standards in operations of oil companies. It is the militarization policy of government that forces the youths in this neglected region to resort to arms-struggle in self defense which tends to exacerbate insecurity in oil producing areas.

- The governments should also educate the local youths and their traditional rulers on the need to protect oil pipelines and avoid vandalism, crude oil bunkering and thefts that are economic sabotage and criminal acts against the country's economy.

- The government should desist from conniving with oil/gas companies to exploit oil/gas producing communities in Nigeria, but instead, force them to pay full and adequate compensation in proven oil/gas spillages for environmental damages to oil/gas producing communities as a matter of justice.

- There should be a wide consultation with local communities before drawing up and executing community based projects and policies in oil producing areas.

- The oil companies operating in oil communities should be part of community service by sitting social amenities for the host oil communities that will go a long way to cement good working relationships with their host countries and engender local and industrial peace and security in such oil communities.

\section{References}

[1]. Abali, D. (1996). Essay on Nigerian Politics and Government: Impact of Oil on Nigeria's Foreign Policy, Foreign Policy Series Vol. 1 No 1.

[2]. Agbu, O. (2005). Oil and Environmental Conflicts in Saliu (1 ${ }^{\text {st }}$ Ed).Nigeria under Democratic Rule (1999-2003) University Press Plc, Ibadan, Nigeria.

[3]. Amnesty International Report (2007).Nigerian Oil Injustice and Violence. The State of the World's Http// the report amnesty.org/eng/regions/Africa/Nigeria.

[4]. Barry, B. (1983). Peoples, States and Fear.Harvester Press, Wheatsheat, U.S.A.

[5]. Bassey, C. \&Oshita O. (2007).Conflict Resolutions, Identity Crisis and Development in Africa.Malthouse Press Ltd, Ibadan, Nigeria.

[6]. Costa, D. (2001). Oil Pollution in Nigeria.Green Nature.

[7]. Ekpenyong A. (2010). The Oil Economy, Environmental Laws and Human Rights Violations in the Niger-Delta Region, Implications and Suggested Solutions.International Journal of Social Policy Research and Development Vol. 1 (2) (2010).

[8]. Ekpo, U. (2004). The Niger-Delta and Oil Politics.Quadro Impressions Limited, Nigeria.

[9]. Esin, O. (2012). Spatial Analysis of Rural Poverty in Akwa Ibom State, Nigeria. Unpublished Ph.D. Thesis (University of Uyo, Uyo, Akwa Ibom State).

[10]. Federal Republic of Nigeria, 1999 Constitution.

[11]. Gurr. Ted, R. (1970). Why Men Rebel; Princeton University Press, Princeton, U.S.A.

[12]. Ikein, A. (1991). The Impact of Oil on a Developing Country: The Case of Nigeria. Evans Brothers Press, Ibadan, Nigeria.

[13]. Ikporukpo, O. (1983). Petroleum Exploitation and the Socio-economic Environmental Justice in Nigeria, Journal of Space and Policy 8 (3).

[14]. Karl, L. (2007). Oil-led Development: Social, Political and Economic Consequences. Centre on Democracy, Development, and the Rule of Law. Journal of the International Studies, Freeman Spogil.

[15]. Leton, B. (1990). Ogoni Bill Right, Port Harcourt.

[16]. Magstadt, M. (2006).Understanding Politics, Ideas, Institutions and Issues. Thomas Wadsworth, U.S.A.

[17]. Nigerian National Population Commission (NPC) Report (2006).

[18]. Niger-Delta Human Development Report (2006).

[19]. Okaba, B (2005). Petroleum Industry and the Paradox of Rural Poverty in the Niger-Delta (1 ${ }^{\text {st }}$ Ed.)Ethiope Publishing Corporations, Benin City, Nigeria.

[20]. Okaba, B. (2003). The State, Oil Multi-nationals and Informal Repression in the Niger-Delta. AFAS Journal of Minority Studies. Vol. 3 (1).

[21]. Okowa, J. (2007). Niger-Delta in the Economy and Politics of Nigeria.Convocation Lecture of the Niger-Delta University, Bayelsa State, Nigeria.

[22]. Osuoka, A. (2003). Politics and Agenda of the Nationality Resistance: The Case of Ijaw of the Niger-Delta. Mathouse Press, Lagos, Nigeria.

[23]. Przerworski, A. (1988). Democracy as a Contingent of Conflicts in J. Ester and R. Slagstad (Eds.) Constitutionalism and Democracy. Cambridge University Press, London. England.

[24]. Phenson, U. (2008). Federalism and Political Violence in the Niger-Delta Region (M.Sc.) Unpublished Dissertation, Department of Political Science/Public Administration, University of Uyo, Uyo, Akwa Ibom State, Nigeria.

[25]. Phenson, U. (2014). Government and the Management of Security Challenges in Nigeria: A Case of Akwa Ibom State (1999-2011). Unpublished Ph.D Thesis, University of Uyo, Uyo, Akwa Ibom State, Nigeria. 
[26]. Shell (Nig.) Petroleum Development Company (SPDC) Reports (2000).

[27]. Sarowiwa, K. (1992). Genocide in Nigeria: The Ogony Strategy. London. Sayes International Publishers.

[28]. United Nations Development Programme Reports (2006).

[29]. 1995 World Bank Reports.Defining and Environmental Strategy for the Niger-Delta 1 (2) Washington, U.S.A.

[30]. 2000 World Bank Reports: Labour Market of University Graduates in Nigeria.

[31]. Yates, A. (1962): Frustration and Conflict. Methuen Press, London.

[32]. Whiteman, M. and Mattord H. (2004).Management of Information Security. Thomson Course Technologies Publication, USA. 